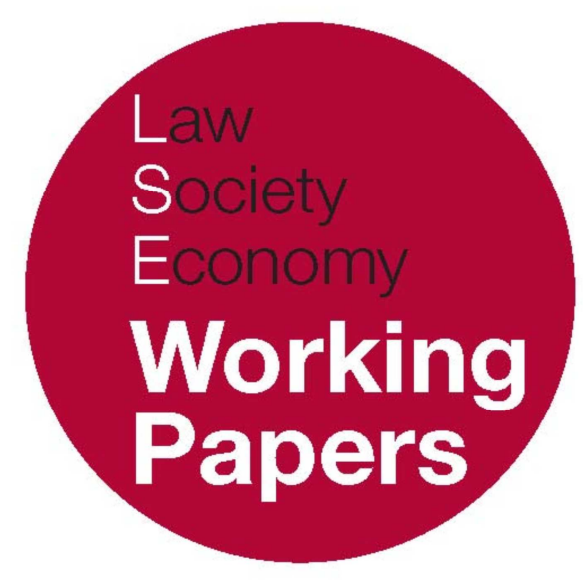

\title{
Reason of State: \\ Whose Reason? Which Reason?
}

\author{
Thomas Poole
}

LSE Law, Society and Economy Working Papers 1/2013

London School of Economics and Political Science

Law Department

This paper can be downloaded without charge from LSE Law, Society and Economy Working Papers at: www.lse.ac.uk/collections/law/wps/wps.htm and the Social Sciences Research Network electronic library at: http://ssrn.com/abstract=2204587.

(C) Thomas Poole. Users may download and/or print one copy to facilitate their private study or for non-commercial research. Users may not engage in further distribution of this material or use it for any profit-making activities or any other form of commercial gain. 


\title{
Reason of State: Whose Reason? Which Reason?
}

\author{
Thomas Poole
}

\begin{abstract}
Since we tend to think of the state as a construct of law, how is it possible for a category of state action to exist somehow outside or beyond the law? Using the term 'reason of state' to specify this special category, the paper asks two more specific questions. When someone talks about reason of state, whose reason and which reason do they mean? Two attempts are made to answer the first question. One attempt seeks inspiration from earlymodern state theory. The second looks to $18^{\text {th }}$ century 'jealousy of trade' politics, particularly the sovereign claims of the East India Company. The second question is addressed tentatively, the paper suggesting (i) that reason of state may be seen as the mirror-image of Coke's defence of the common law as artificial reason and (ii) that the basic structure of reason of state may be identified as semi-secret, based in reason allied to experience, offering guiding intelligence, and sovereign in a 'soft' sense.
\end{abstract}

* Reader in Law, London School of Economics and Political Science. 


\section{INTRODUCTION}

This paper seeks to unravel a puzzle. The puzzle can be put any number of ways. But I will present it in this way. Given that we conceive the state principally as a construct of law that acts only through law, how is it possible for a category to exist somehow outside or beyond the law?

Now, there are a number of ways of describing this power that is somehow beyond (or hors catégorie) the law. Different jurisdictions use different terms. But even within a particular jurisdiction it is common to see an array of synonymous or near-synonymous terms used to frame arguments in this area. Sticking with the jurisdiction I know best, legal argument in English courts, depending on the era, the context or what the advocates think might fly, tends to group around the following ideas: prerogative; 1 matter of state; ${ }^{2}$ martial law; ${ }^{3}$ political acts; ${ }^{4}$ emergency powers; $;^{5}$ executive plenary discretion; ${ }^{6}$ defence of the realm; ${ }^{7}$ arcana imperii (secrets of state). ${ }^{8}$

Each of these phrases has a considerable lineage and captures something important or distinctive about our theme. But in this paper I use the term 'reason of state' to specify this special category. I do not regard this as an arbitrary choice between basically interchangeable umbrella terms. Rather, I suggest that the terminology of reason of state best captures what is special about the category in question. Some of the other terms are too limited to act as a term for the whole category - martial law being an obvious case in point. Others, like prerogative, tie the category too closely to a particular form or expression of power. As well as being suitably capacious, reason of state directs our attention in a way that the alternatives don't quite to two bundles of associated themes that take us closer to the heart of the matter. First, the idea of agency or personality in the context of the law-governed state. Second, the idea of reason and of reason-giving in the institutional interstices of the state. The terminology of reason of state takes us directly into these matters. It also connects the legal problem outwards into even older and richer discourses about law and political authority.

The paper is structured as follows. It makes two attempts at answering the question 'whose reason?'. The first attempt - or iteration - seeks inspiration from $17^{\text {th }}$ century state theory, contrasting Hobbes's theory of the state as artificial legal creature with the more sceptical reason-of-state theorists that preceded him. The second iteration looks more to the $18^{\text {th }}$ century and the world of constitutional

\footnotetext{
${ }^{1}$ See, e.g., Darnel's Case (1627) 3 State Trials 36 (Five Knights' Case); Hampden's Case (1637) 3 State Trials 825 (Case of Ship Money).

2 See, e.g., Bates's Case (1606) 2 State Trials 371 (Case of Impositions).

${ }^{3}$ See, e.g., Ex parte D.F. Marais [1902] AC 109.

${ }^{4}$ See, e.g., Chandler v Director of Public Prosecutions [1964] AC 763.

${ }^{5}$ See, e.g., A v Secretary of State for the Home Department [2004] UKHL 56.

${ }^{6}$ See, e.g., Liversidge v Anderson [1942] AC 206.

7 See, e.g., R $v$ Halliday, ex parte Zadig [1917] AC 260.

8 William Blackstone, Commentaries on the Laws of England [1765] Bk 1, Ch 7.
} 
practice in the age of 'jealousy of trade' politics, focusing on how the sovereign claims of the East India Company were handled in British courts. The final section attempts an answer to the question 'Which reason?' by bringing together the insights derived particularly from Section 2 .

\section{WHOSE REASON? FIRST ITERATION - STATE (17TH CENTURY)}

The first question that this paper sets out to answer seems at first sight to be too obvious to be worth the effort. 'Whose reason? Why, the State's of course!' But a little reflection should show that this easy rejoinder cannot dispose of the question. One of the characteristics of the common law has been its insistence that a 'law of State' outside and above the common law is unknown. ${ }^{9}$ As Lord Camden in what is perhaps the classic English civil liberties case, Entick $v$. Carrington, put it: 'With respect to the argument of State necessity or a distinction that has been arrived at between State offences and others, the common law does not understand that kind of reasoning. ${ }^{10}$ A century on, Dicey - perhaps the closest thing our ramshackle constitution has to a founding father - generalized the point. The rule of law stood, for him, not just for the absolute supremacy of ordinary law over arbitrary power but also the more specific proposition that 'no man is punishable or can be lawfully made to suffer in body or goods except for a distinct breach of law established in the ordinary legal manner before the ordinary courts'. ${ }^{11}$

My point in referencing these familiar bits of the legal canon is not to wax lyrical about the common law constitution or to say something about the liberal character of the British state tradition. If you think about it, what both Lord Camden and Dicey are saying about liberty under law is in fact double-edged. They are not saying that there are certain things that no government can do - they are not absolute natural rights theorists. No, they say that government can only act to the detriment of the individual if it acts through normal legal processes, processes that are subject to the ordinary courts (but not on grounds of constitutional review). Now, this might make government less likely to act illiberally, given certain exogenous conditions to do with political context and public opinion (that last one a Diceyan favourite). ${ }^{12}$ Certainly both Lord Camden and Dicey hope so. They were both Whigs, after all, albeit of different stripes in different eras. But nothing in their constitutional theory stops government from acting illiberally. What the theory does is to make it harder for government to act

9 William Harrison Moore, Act of State in English Law (New York: E.P. Dutton, 1906), 22.

${ }^{10}$ Entick v Carrington (1765) 19 State Trials 1030.

11 Albert Venn Dicey, Introduction to the Study of the Law of the Constitution [1885] Ch 5.

12 Albert Venn Dicey, Lectures on the Relation between Law and Public Opinion in England during the Nineteenth Century (Indianapolis: Liberty Fund, ed. Richard VandeWetering, 2008). 
in an arbitrary way - where 'arbitrary' is understood in the first instance formally, as an act not done in the normal legal way.

What is going on here is the articulation at the level of law and legal practice of the general principles of state theory. To see why this is so we can turn to the foremost early-modern theorist of the state, Thomas Hobbes. We sometimes think of Hobbes as an advocate of absolute rule, of civic life under a sovereign unlimited by law and imbued with the quasi-divine attributes of a 'mortal god'. But this reading of Hobbes is either plain wrong or at least incredibly partial. Hobbes himself no doubt bears some responsibility for this. His image of the state as the great leviathan is so strong - for Carl Schmitt, the most powerful image in the whole history of political theory - that it tends to colour our view of the theory as a whole. For Hobbes's theory is decidedly not a proposal for personal rule - quite the opposite. Hobbes presents us with both an image of the state as a juridical construct, a creature of law, and with arguments about why we should obey it. This theory of state as encompassing the totality of legitimate rule means precisely that there is no room - or almost no room ${ }^{13}$ - for private or otherwise non-state forms of legitimate political authority (including alternative sites of legal authority - ecclesiastical law, customary law, natural law, etc.). The state or 'commonwealth' is entirely the product of human artifice. (Hobbes insists that our natural tendency, contrary to Aristotle, would be to live in a world in which man is wolf to man: homo bomini lupus.) To live in the civil condition means, then, to live unnaturally, to act out our roles as official holder or judge or subject, as the case may be, as though permanently on a public stage. The law constitutes the framework in which we operate in this manner. It also acts as the transmission cables of authority, providing the 'Artificiall Chains' that link sovereign and subject. A law is the way one part of the body politic communicates with another. That Hobbes is serious about the communicative function of law is shown by the weight he places on the duty to promulgate and publicize laws. ${ }^{14}$ Law, he insists, is simply not valid if it is not publicized properly, which means passed in the normal way and then actively brought directly to the attention of the subjects. 'Knowledge of the laws depends on the legislator, who has a duty to promulgate them, for otherwise they are not laws.' 15

Hobbes's vision of politics, then, is in two senses law-governed. At the general level, it purports to offer a 'civil science' - a set of propositions (or 'laws' in the scientific sense) for government by means of the well-ordered, peaceseeking commonwealth. At another level, it offers a prescription for rule through

13 A question explored in Thomas Poole, 'Hobbes on Law and Prerogative' in David Dyzenhaus and Thomas Poole (eds), Hobbes and the Law (Cambridge: Cambridge University Press, 2012).

${ }^{14}$ See Jeremy Waldron, 'Hobbes and the Principle of Publicity' (2002) 83 Pacific Philosophical Quarterly 447.

15 Thomas Hobbes, De Cive, 160. On the formalities of publicity Hobbes envisaged see A Dialogue Between a Philosopher and a Student, of the Common Laws of England in Alan Cromartie and Quentin Skinner (eds), Thomas Hobbes: Writings on Common Law and Hereditary Rights (Oxford: Oxford University Press, 2008), 32. 
the application of ordinary law. While the chutzpah of both of these claims is little short of breathtaking, it is apparent that Hobbes's theory in principle leaves little to chance and next to nothing to personal discretion or caprice. The ambition is apparent from the start. The first paragraph of Leviathan sees images of art and artifice piled on top of each other: 'art of man' - 'artificial animal' - 'artificial man' - 'automata' - 'machine'. Pulling back the curtain discloses the state, that $\mathrm{man} /$ beast/god/myth itself, as nothing but a 'huge machine, a gigantic mechanism in the service of ensuring the physical protection of those governed'. ${ }^{16}$ The sovereign, while in principle unlimited by law, has no effective choice (if he wants both to action his power and to remain sovereign) but to operate through the densely bureaucratic apparatus of law and legal rule.

Had Hobbes's aim been to explain and justify personal rule he would have gone about his task very differently. In fact, his state theory can be seen as an argument against precisely that position, represented in his time by the wellestablished tradition of reason of state thinking. The tradition had its roots in a reading of Machiavelli - the Machiavelli of The Prince rather than the republican Discourses - according to which the point of political writing should be to offer advice on how to 'maintain one's state'. ${ }^{17}$ The approach was alien to the humanist and scholastic orthodoxy, the aim of which was to elaborate principles of justice and law that ought to govern the polity. This new language of politics was brought into greater focus by the other great Florentine political author of the cinquecento, Francesco Guicciardini, who was the first to use the expression ragion di stato (reason of state). Recognizing perhaps more clearly or consistently than Machiavelli that the humanists' language of politics was not up to the challenge of the times, Guicciardini shifted the focus of politics decisively away from civil philosophy (ethics and law) to the art of state, understood as a derivation of the art of ruling a household and the art of commerce more generally (economics). ${ }^{18}$ This style of politics spawned a whole genre, Giovanni Botero's notable Ragione di Stato [1589] being but the first of a whole shelf of books with that sort of title. ${ }^{19}$ This body of work fed into a wider current of $16^{\text {th }}$ century political thought that, influenced no doubt by the extreme violence of contemporary politics, was characterized by a mood of skepticism and disenchantment and a revival of interest in Tacitus, the chronicler of the dark times of early imperial politics in

${ }^{16}$ Carl Schmitt, The Leviathan in the State Theory of Thomas Hobbes (Chicago: University of Chicago Press, ed. George Schwab, 1996), 34-35.

${ }^{17}$ Quentin Skinner, The Foundations of Modern Political Thought, Vol. 1: The Renaissance (Cambridge: Cambridge University Press, 1978), 250.

18 Maurizio Viroli, From Politics to Reason of State: The Acquisition and Transformation of the Language of Politics 1250-1600 (Cambridge: Cambridge University Press, 1992), ch 4. See p 262: 'Reason of state concerns interest and the new political man, the statesman, is not supposed to rule for the good of his subjects, but for his own. The world is nothing but a great public shop and the purpose of merchandising to gain. Politics is no exception.'

19 Peter Burke, 'Tactitism, Scepticism, and Reason of State' in J.H. Burns (ed.), The Cambridge History of Political Thought 1450-1700 (Cambridge: Cambridge University Press, 1991), 479. 
Rome. ${ }^{20}$ Within this approach to politics, justice is relegated in favour of 'interest', ${ }^{21}$ law loses out to 'necessity', 22 and reason to 'prudence'. Unsurprisingly, none of these reason-of-state thinkers were constitutionalists. Nor were they particularly concerned with the traditional civic virtues: 'all were persuaded of the importance of interest, and of the power of necessity. They also shared the same attitude towards the means by which the grandezza of a state was to be secured'. ${ }^{23}$

Out of this politics of prudence and interest came also a strategic way of thinking about ruling. Reason-of-state thinkers 'made politics seem $[. .$.$] like a$ complex and ruthless game in which all players are self-interested and power is the prize'. ${ }^{24}$ If they wanted to survive in this game, participants needed to wise up. One thing they needed to do was to learn the art of dissimulation and deception ${ }^{25}$ - saying one thing while believing another, adapting your behaviour to match the plebs' expectations, reserving any real power for yourself while offering the people a simulacra of liberty, and so on. 'Much of the art of ruling thus consists of making deceptions of various kinds: these, the "arcana imperii", were easily identified with the strategems of the Machiavellian prince.'26 Politics becomes the art of duplicity, foundational to which is the prioritization of private (interest) over public (reason).

This brief examination of reason-of-state thinking brings out more precisely the nature of Hobbes's theoretical enterprise. Hobbes certainly shares the reasonof-state theorists' scepticism about the ability of people to live naturally in harmony. He is equally dyspeptic (or 'realist') about the capacity of reason to achieve peace. And he is as open as they are about force being a basis for civil life. But Hobbes reroutes these basic insights in a radically different direction. Instead of a shapeless and ungrounded politics based on shifting calculations of selfinterest, he articulates a civil science that identifies the architectonic structure of political rule. If we follow the prescriptions set out in Leviathan, he insists, we should in large measure be able to ditch prudence, interest, and even perhaps necessity from the management of the state. The sovereign is not like the prince. The prince is decidedly a person, exercising power in his own private interest. The sovereign is just part of a machine that we call the state. 'He' is a formal creation, a piece of legal artifice. 'He' exists as law, exercises power through law, and speaks through law. 'His' purpose is the security and well-being of the people of the

20 The Dutch writer Lipsius and the Frenchman Montaigne being central figures in what has been called the 'new humanism': see Richard Tuck, Philosopby and Government 1572-1651 (Cambridge: Cambridge University Press, 1993).

${ }^{21}$ Botero, Reason of State, 41: 'reason of state is little else than the reason of interest'.

22 An idea pithily expressed in a pamphlet from the pamphlet wars of the English Civil War: 'Reason of state is something more sublime and imperiall than Law' (The Contra-Replicant sig. CIV, 1643) 231.

${ }^{23}$ Tuck, 80 .

${ }^{24}$ Noel Malcom, Reason of State, Propaganda, and the Thirty Years' War (Oxford: Oxford University Press, 2007), 96

${ }^{25}$ Francis Bacon wrote an essay 'Of Simulation and Dissimulation' in which he put forward a case for 'mixed prudence'.

${ }^{26}$ Malcolm, Reason of State, 96. 
commonwealth. The private is once again subordinate to the public. Private interest and judgement being cancerous to the body politic, it is made subject to the judgement of the sovereign (that is, of the laws). And that judgement is of necessity public. The sovereign bears our persons in its person, so bis decision is really our decision. And, if it sticks to the plan set out in Leviathan, which he must do, his 'private' interest is identical to the public interest of the commonwealth. What you get with Hobbes, to sum up, is a structure of rule that is open and public, direct and formal. As he says in De Cive, the state 'does not want to take anything away from the citizen in underhanded ways, and yet it is willing to take everything from him in an open fashion'. ${ }^{27}$

Let us start to retrace our steps to the question raised at the start of the section. We now have at least two versions of 'reason' in play and two versions of the 'state'. The 'reason' of reason-of-state theory is a straightforward calculation of (the ruler's) self-interest; and the 'state' understood as a personal thing connoting the relationship between a particular ruler or ruling group and the jurisdiction in their possession or under their control. It is the reason of economics, or game theory. By contrast, the 'reason' of modern state theory looks more like a conclusionary statement, a label we attach to something that has been through a certain formal process - or at least something that only takes shape within a particular institutional and formal context (the state). The sovereign acting through normal legal channels. It is the 'reason' of law, where law is understood as formal, institutional, and positive. ${ }^{28}$

We can now make better sense of what common lawyers like Lord Camden and Dicey are saying when they deny a category outside the ordinary law. ${ }^{29}$ They are doing no more and no less than realizing state theory in the praxis of the law of the constitution. Their point is that we don't have rulers so much as we are ruled by a state, which means a creature of the law. On this account, the state can only 'reason' in the elaboration through normal legal channels of legitimate law. Anything else is neither 'reason' nor 'law'. It is brute force. We see this position reflected in the way Dicey responds to the problem of sudden emergencies, which he discussed in the context of martial law. ${ }^{30}$ If faced with an emergency, you use your power to deal with it - a prima facie non-legal act - and then seek retroactive validation of that exercise of power through the normal route (in his context, Parliament). For these lawyers, any other approach to reason-of-state claims is either a category error - in that it misunderstands the nature of law and authority or else a power grab aimed at reinstating personal rule - which is how the reigns

27 Thomas Hobbes, On the Citizen (Cambridge: Cambridge University Press, Richard Tuck and Michael Silverthorne eds, 1998), 86.

${ }^{28}$ Dialogue, 19: 'the Kings Reason, when it is publickly upon Advice, and Deliberation declar'd, is that Anima Legis, and that Summa Ratio, and that Equity which all agree to be the Law of Reason'.

${ }^{29}$ Note too the influence of Hobbes on later Whig political thinking (both Camden and Dicey were Whigs of various sorts): see Tuck, 345: 'it was the Whigs rather than the Tories who could be seen as his intellectual heirs to the eighteenth century'.

30 See David Dyzenhaus, 'The Puzzle of Martial Law' (2009) 59 University of Toronto Law Journal 1. 
of Charles I, Oliver Cromwell (during the Protectorate), and James II came to be interpreted. The sovereign can only act (legitimately) through the state form.

There is an alternative to the rigid position of the common lawyers, one that is still (just about) consistent with modern state theory. On this account, reason of state might refer to the reason of the sovereign not acting as the state. This was in essence Locke's solution. Although elements of Locke's theory differ substantially from Hobbes's, they share the same concern to articulate the state in formal and institutional terms. The burden of Locke's theory lies in its insistence that the powers of government 'ought to be exercised by established and promulgated laws'. ${ }^{31}$ But whereas Hobbes tends, while emphasizing the legally unrestricted power of the sovereign, to avoid the claim of special executive powers, Locke explicitly permits the executive (the king) to exercise extraordinary discretionary powers in times of crisis. ${ }^{32}$ These informal (or anti-formal) powers are described as operating extra et contra legem - they take their shape against the normal system of civil law - and there is no doubt that in this account prerogative power is invested in the person as well as the office. ${ }^{33}$ It is as though Locke throws up his hands, and says that this is honestly as far as the impersonal theory can go in eradicating the idea of personal rule. But the price paid for such honesty is high. The prerogative power only fits with the underlying state theory in the sense that it provides an exception to it - and a potentially massive one at that. Justified by necessity, grounded in notions of personal rule, legitimated on the basis of whether or not it works: Locke's prerogative is a bit of reason-of-state theory dropped like a bombshell into state theory that carries the potential to explode the whole thing.

\section{WHOSE REASON? SECOND ITERATION - EMPIRE (18TH CENTURY)}

Another way into reason of state is to look more closely at the way the idea took shape and evolved in constitutional practice. In this section, I approach the question 'whose reason?' by looking at a line of important cases that involve the East India Company and its claim to exercise monopoly and sovereign powers. The largest of the chartered companies at the vanguard of the expansion of British trade and influence overseas, the Company 'exercised an enduring influence on British politics'.34 The political and commercial stakes that surrounded the

\footnotetext{
31 John Locke, Second Treatise of Government, II, s.137.

32 John Dunn, The Political Thought of John Locke (Cambridge: Cambridge University Press, 1982)

33 See, e.g., Clement Fatovic, Outside the Law: Emergency and Executive Power (Baltimore: Johns Hopkins University Press, 2009), 65; Thomas Poole, 'Constitutionalism Exceptionalism and the Common Law' (2009) 7 International Journal of Constitutional Law 247.

34 John Brewer, The Sinews of Power: War, Money and the English State, 1688-1783 (Cambridge, Mass.: Harvard University Press, 1988), 169.
} 
Company were massive, and produced a number of reason of state cases played out in the context of Britain's expanding commerce-based empire.

As public lawyers, our interest in these cases relates not to questions of empire so much as what we might call the feedback effects of Britain's imperial adventures on constitutional development. Painting with a broad brush, we might say that $17^{\text {th }}$ century England was the era of (sometimes literal) battles over basic questions of sovereignty and state form. These questions were largely shelved in the wake of the 'Glorious Revolution' of 1688-9. Thereafter, purely domestic cases involving fundamental questions, including questions of reason of state, were less frequent. ${ }^{35}$ But the increasing involvement of British people - and British corporations - in overseas ventures, and the increasingly active role of the British state in global politics, produced its own stream of litigation - not to mention Parliamentary debates and inquiries ${ }^{36}$ - which naturally raised novel questions, some of fundamental importance. These cases produced not just the legal principles that framed Britain's colonial and imperial relations, but also helped to forge the constitutional identity of the modern British state. ${ }^{37}$ They show, then, the extent to which the ideological pretensions of the British Empire to be 'Protestant, commercial, maritime and free'38 were instantiated in law.

\section{Defining the Prerogative of Trade (With Infidels)}

Trade between Europe and Asia had existed since Roman times. But the 16 th and early $17^{\text {th }}$ centuries saw a spectacular growth in long-distance trade as a result of better shipping and navigation, greater purchasing power among European elites, and more effective commercial organization. ${ }^{39}$ This trade involved big risks of the sort that only governments or large combinations of merchants could handle. England being in this period a relatively weak state, its overseas activities - war, trade, settlement - were typically 'undertaken by means of an administrative repertoire of delegation and "government by licence". 40 The East India Company followed the model of established companies trading in Virginia, Hudson Bay, West Africa, and the Levant. It obtained a Charter from the Queen in 1600 giving

35 Although it is probably worth noting that many of the $17^{\text {th }}$ century reason of state cases were not 'purely domestic' but also involved questions to do with commercial trading and customs duties (e.g. Bates's Case; Five Knights Case) or do with the relationship between the Crown and 'foreign' subjects (e.g. Calvin's Case, 1608). On the significance of the latter case see, e.g., Mary Sarah Bilder, The Transatlantic Constitution: Colonial Legal Culture and Empire (Cambridge, Mass.: Harvard University Press, 2004), 36.

36 A classic example - also involving the East India Company - was the impeachment proceedings before Parliament of Warren Hastings, former Governor-General of India, between 1788-1795 in which Edmund Burke played a starring role. See e.g., Nicholas B. Dirks, The Scandal of Empire: India and the Creation of Imperial Britain (Cambridge, Mass: Harvard University Press, 2006).

${ }^{37}$ For a broader discussion of that theme see, e.g., Linda Colley, Britons: Forging the Nation, 1707-1837 (New Haven: Yale University Press, $2^{\text {nd }}$ ed., 2005).

${ }^{38}$ David Armitage, The Ideological Origins of the British Empire (Cambridge: Cambridge University Press, 2000), 8.

39 Peter James Marshall, 'The English in Asia to 1700' in Nicholas Canny (ed.,) The Oxford History of the British Empire, Vol. 1: The Origins of Empire (Oxford: Oxford University Press, 1988), 264.

${ }^{40}$ Michael J. Braddick, 'The English Government, War, Trade, and Settlement, 1625-1688' in Canny, Origins of Empire, 286. 
it exclusive rights to trade with the East Indies (as well as authorizing it to indulge in privateering on the side should the opportunity arise). ${ }^{41}$

The Company soon became by far the largest of the English chartered trading companies. Naturally, other merchants wanted a piece of the action. The grant of exclusive trading rights made that difficult. A group of merchants might obtain from the Crown a privilege to trade against the Company's monopoly. But even if they couldn't, the legal authority that underpinned that grant - the prerogative was becoming a bone of contention in itself and so might potentially be undermined. Parliament in particular became increasingly exercised by the king's power to raise money through this extra-parliamentary route. Now, the relationship between elite merchants and the Crown should have been mutually supporting. Merchants needed the king's permission to trade overseas (by no means a given) and legally enforceable monopolies helped protect profits from that trade. The crown got in return a very useful source of financial support, via loans, 'gifts' and sweeteners, and taxes on trade. Things did not always go smoothly. Some merchants would no doubt have nursed grievances about what they saw as their small share of the pie. But even the luckier ones like the East India Company were not always happy. The king sometimes sold permission to trade against a Company's monopoly. ${ }^{42}$ Sometimes he upped the customs levy. Occasionally he failed to renew a Company's Charter altogether, making it impossible to trade. The lack of certainty that ensued led even the cream of London's merchants into conflict with the Crown at certain points. The period leading up to the Petition of Right 1628 was particularly rocky. But while the socalled 'new merchant' leaders began to gravitate towards republicanism and coalesced around Parliament, the old merchant elite, centering on the Levant and East India Companies, stuck with the King. When the king lost out to Parliament in the Civil War, the result was that the old elite spent the years of the republic in the political wilderness. ${ }^{43}$

Our first case - one of the great cases of the $17^{\text {th }}$ century, but little known amongst lawyers - comes from the period after the fall of the republic, with the king restored to the throne and the fortunes of the East India Company very much on the rise. James II's reign saw near-complete commercial and strategic harmony between the Crown and the Company. Indeed, Sir Josiah Child, the merchant who had muscled his way into the control of the Company, also acted as the king's economic adviser. The two shared commercial interests - the King was a big investor in the Company. They also shared the same 'Tory' vision of political

\footnotetext{
${ }^{41}$ John C. Appleby, 'War, Politics, and Colonization, 1558-1625' in Canny, Origins of Empire, 69.

${ }^{42}$ For instance, the Courten Association received a valuable grant from Charles I in 1635 that gave them the right to establish trade at Goa, China, Japan, Malabar, and other parts of the East Indies. The Association's established a colony on Madagascar which was a total failure. See Alison Games, The Web of Empire: English Cosmopolitans in an Age of Expansion 1560-1660 (Oxford: Oxford University Press, 2008), ch 6.

43 Robert Brenner, Merchants and Revolution: Commercial Change, Political Conflict and London's Overseas Traders, 1550-1653 (Cambridge: Cambridge University Press, 1993), ch 1.
} 
economy and imperial policy, central to which was a belief that wealth was a zerosum game in which the imperative was to control territory. ${ }^{44}$ This vision connected with the King's modern Catholic state policy. Following the blueprint of Louis XIV of France, James's ambition was to create a centralized modern state system in which a vastly augmented bureaucracy radiated from a monarch vested with apparently limitless prerogative powers. 45

It was in this climate that the Company brought proceedings against Thomas Sandys for outfitting a ship with the intention of making an unauthorized voyage to the East Indies. Clearly more than commercial interest was at stake. Forwarded as a constitutional matter to the Court of King's Bench, East India Company v. Sandys (1682) was argued by London's top lawyers and became known as the 'Great Case of Monopolies'. The case turned on a series of fundamental questions of principle, concerning monopolies and prerogative on one hand, and the politics of empire on the other. Sandys's position was far from hopeless. Monopoly was a product of the royal prerogative and, as such, tended to be associated with the undermining of the liberty of both Parliament and the subject. ${ }^{46}$ Parliament had in fact passed a series of anti-monopoly measures during the course of the century. The Company's lawyers accepted that monopolies were illegal according to common law. They argued instead that the Company should not be treated as simply a private monopoly merchant.

The argument was articulated on three main levels. The first related to free trade, and so connected to those late-1 $17^{\text {th }}$ century fundamentals, the right to liberty and property. Drawing on basic 'free seas' principles the Company had once used against the Portuguese and Dutch, ${ }^{47}$ Sandys argued that 'the King cannot take away goods that a man has got by his trade, much less can he take away his whole trade'. The Company's response was that only a managed trade worked when distances were so great and the dangers so real; and only a monopoly organization could offer effective management. ${ }^{48}$ This first point led into the second. The East Indies trade was not a matter of pure commerce but was bound up with diplomacy and considerations of state policy. There being a religious dimension in play, the king has a special interest in regulating commerce with the infidel inhabitants of the East Indies. Only a Christian prince could authorize interaction with infidels, such engagement being unnatural for a Christian subject. (Sandys's lawyers responded by suggesting that 'religion too often has been made a cloak and veil for other ends and purposes'.) A third argument concerned more directly

${ }^{44}$ Steve Pincus, 1688: The First Modern Revolution (New Haven: Yale University Press, 2009), 381.

${ }^{45}$ Ibid., 160-162.

46 Anne L. Murphy, The Origins of English Financial Markets: Investment and Speculation before the South Sea Bubble (Cambridge: Cambridge University Press, 2009), 74.

47 Armitage, Ideology Origins of the British Empire, 111-112, nothing how the English East India Company in 1612-13 used the principle of the freedom of the seas, which the Dutch East India Company had (through Grotius) recently asserted against the Spanish and Portuguese, against the Dutch themselves; 'most ironically of all, that principle was thrown in the face of Hugo Grotius himself, who was one of the four Dutch commissioners sent to negotiate with the English East India Company'.

${ }^{48}$ For a full defence of the Company's monopoly on this point see Josiah Child, A New Discourse of Trade (London, 1693). 
the scope of the king's prerogative. For the Company, foreign trade and international relations had always been under the exclusive purview of the monarch. Sandys's lawyers allowed that ' $[\mathrm{t}]$ he prerogative is great', but suggested that 'it has this general and just limitation, that nothing is to be done thereby that is mischievous or injurious to the subject.' The cumulative effect of these arguments, or so the Company's lawyers argued, was to put the investigation of the Company's trade into a different legal bracket, one where the court apply the common law alongside, or in light of, 'such other Laws also as be common to other Nations as well as ours ... namely the General Law of Nations, the LawMerchant, the Imperial or Civil Law.' ${ }^{39}$

The judges sided with the Company on all counts. That they affirmed such an expansive view of the king's prerogative is unsurprising. Only a few years separate the decision from Godden v. Hales (1686), the high-water mark of the prerogative, which held that the king had a power to dispense with the laws. ${ }^{50}$ The judges in EIC v. Sandys saw things largely from the perspective of the Crown, seeing it as a case of enormous importance for defining the king's powers. ${ }^{51}$ The king had the 'undoubted prerogative' to grant exclusive trading charters, a power that his courts would protect. The Company could not be an illicit monopoly because it was not a private body in the normal sense. It acted for the public good, largely because it was performing at the king's behest tasks that the king would himself accomplish directly through his own agents if he could.

The judgment thus seems to confirm James II's plan for the British monarch to assert its dominance over the seas, ${ }^{52}$ with the Company as one of his arms of enforcement - and no doubt this is what the judges intended. As such, it is true to the structure of delegated administrative authority that characterized the early years of overseas expansion. ${ }^{53}$ But things are rather more complicated. We need to bear in mind, first, that many of the royal grants and patents that had come the Company's way since 1600 contained what were in effect 'attributes of sovereignty', such as the right to dispose and alienate land, to levy taxes, to use

49 It may or may not be coincidental but earlier in the century the civil law was (rightly or wrongly) thought of as a source of expansive accounts of the prerogative. See, e.g., John Cowell, 'Prerogative of the King' in Cowell, The Interpreter, or, Booke Concerning the Signification of Words (Cambridge, 1607). The position is consistent with Sir Matthew Hale's Prerogatives of the King, written in the 1650s, where the king's absolute royal prerogative over newfound lands and the limited agency of the common law is asserted.

50 '[T] he laws of the England are the King's laws', Herbert CJ opined, and 'that it is an inseparable prerogative in the King, to dispense with penal laws upon necessity and urgent occasions' and that 'the King is sole judge in that necessity'.

51 Jeffreys CJ declared the case to be 'of so great concern and consequence as perhaps there was none other ever so great (I am sure none greater) in Westminster Hall wherein the prerogative of the King was more concerned on the one hand, and the liberty and property of the subject on the other.'

52 Armitage, Ideological Origins of the British Empire, 123.

${ }^{3}$ Ken MacMillan, Sovereignty and Possession in the English New World (Cambridge: Cambridge University Press, 2009), 6: 'the English crown had a legal sovereign, prerogative, and imperial obligation to authorize, supervise, protect, and proclaim its overseas holdings, particularly when faced with challenges from other European colonizing monarchs'. 
martial force, and to make laws 'for the good government' of any territory that they controlled; ${ }^{54}$ and, second, that the vast distances that were in play made it impossible for the crown to exercise any control or oversight in relation to the Company's activities. In this context, the Company took the decision in Sandys as a green light to transform itself from 'a parcel of mere trading merchants or peddlers' into a 'formidable martial government in India'. ${ }^{55}$ As it turned out, Sandys's lawyers had been on to something when they suggested in court that siding with the Company would make it legally unaccountable, 'independent from the government' and, as such, 'a sort of republic for the management of trade'. As one Company servant would say to another in later years, "we are under another Law'.56 Arguing for the king's prerogative, the Company was also arguing the king out of his prerogative.

\section{'The Merchant is Become the Sovereign'}

We pick up the thread of the story at a point where these more audacious claims about the sovereign capacity of the East India Company are being aired openly in court. But before we do we need to pause to reflect on the following questions. Wasn't James II's whole plan for a centralized modern state along French lines, including assertive use of royal prerogative, swept away by the Glorious Revolution of 1688-9? And, if it was, why give so much attention to a case, no matter how important, from that failed period? These questions raise bigger questions about the impact of the Glorious Revolution, often regarded as the British constitution's founding moment, ${ }^{57}$ which can only be touched upon here. On the face of things, the Revolution looked like bad news for the Company. The new regime had a new ideological orientation and a very different vision for trade and empire.58 The precedent established in EIC $v$. Sandys looked decidedly precarious. A similar case brought by the Royal African Company against private traders in 1689 ended with the court ruling against the Company, thus opening the way for interlopers to engage (lawfully) in foreign trade. ${ }^{9}$ The ruling was confirmed by Parliament in 1693/4 when it acknowledged that 'it is the right of all Englishmen to trade to the East Indies, unless prohibited by act of Parliament'. 60

\footnotetext{
54 Stern, Company-State, 23.

55 Pincus, $1688,378$.

56 Stern, Company-State, 59.

${ }^{57}$ John Greville Agard Pocock, 'The Significance of 1688: Some Reflections on Whig History' in Pocock, The Discovery of Islands: Essays in British History (Cambridge: Cambridge University Press, 2005), 119: 'the English of 1688 did not re-enter, and as things turned out they forever left, the world of politics as Hobbes and Locke had known it'.

58 Pincus, 1688, 393: 'The Glorious Revolution, then, produced, and by many was intended to produce, a revolution in political economy. ... The Whigs, many of whom had been supporters of the East India interlopers, thought that wealth was created by human endeavor and thus potentially infinite. While these political economic thinkers, writers and actors initially focused their energies on breaking up mercantile monopolies, in particular that of the East India Company, they quickly shifted their emphasis to creating a national bank. The revolution in political economy was thus a prerequisite to the Financial Revolution.'

59 Nightingale v Bridges (1689).

${ }^{60}$ W. Darrell Stump, ‘An Economic Consequence of 1688’ (1974) 6 Albion 26.
} 
But Lampedusa's observation about epochal change - that everything must change so that everything might stay the same - is particularly apt in respect of the Glorious Revolution. ${ }^{61}$ No doubt the Revolution saw a refocusing of the ideological orientation of the state - more Protestant, more commercial, and antiFrench. But many of the key late Stuart reforms, most notably to the fiscal structure of the state, were taken up with vigour in the decades after 1689. This is not just a reflection of the basic pragmatism of (English) political elites, although it is probably a truism that '[a]bove all else England's constitution has been mutable and its principles riddled by compromise. ${ }^{62}$ It also reflects the growing realization that, in the new climate of $18^{\text {th }}$ century politics, the 'fiscal-military' state whose outlines James II had sketched was the best way to protect English liberties. This English 'constitutional moment' presents us, then, with something of a paradox. The Revolution was fought on principles of liberty and property (and Protestantism). And within the new order greater formal constraints were imposed on government - Parliament moved from watchdog of government to a central part of government. But these greater constraints made it easier to advance plans for strengthening and expanding the state.

The Glorious Revolution was not only a Protestant but a "country" revolution, concerned both to preserve the true faith as England's official religion and to reduce the powers of central government. But, in order to protect the revolution from its enemies, the powers of the state had perforce to grow as never before. ${ }^{63}$

The new political reality helps to explain why the Company, having found itself on the wrong side of a Revolution and with very few friends in high places, managed to negotiate the regime change in pretty good shape. ${ }^{64}$ Arguments of state necessity, while resented in principle, had more purchase than ever before, and the new regime was much more inclined to assert itself internationally. This was particularly true of commercial politics, which came to be seen throughout Europe as a matter of national survival. David Hume used the expression 'jealousy of trade' 65 to describe what he saw as the pathological conjunction between politics and the economy that had turned the globe into a theatre of perpetual commercial

${ }^{61}$ John Greville Agard Pocock, 'Empire, State and Confederation: the War of American Independence as a Crisis in Multiple Monarchy' in Pocock, Discovery of Islands, 140: 'the Revolution of 1688-9 takes on the character of a "second Restoration": a reconstruction, but at the same time re-stabilization, of the conditions under which crown, parliament and national church could co-exist'.

${ }^{62}$ Julian Hoppit, A Land of Liberty? England 1689-1727 (Oxford: Oxford University Press, 2000), 13.

${ }_{63}$ Brewer, Sinews of Power, 142.

${ }^{64}$ It did, though, have to swallow the creation of a rival New East India Company in 1698. (The New Company offered a financially desperate government a $f 2$ million loan.) The Old Company bought into the New Company and the two Companies agreed to merge (completed in 1709) as the New Company ran into difficulties. See Poppit, Land of Liberty?, 275.

${ }^{65}$ Hume, 'Of the Jealousy of Trade' (1758). 
war. ${ }^{66}$ Based on the 'categorical imperative of protecting the republic against external threat', this was the politics of necessity in new, commercial garb, and played out for the first time on a global stage. 'Jealousy of trade was the application of reason of state to international trade. ${ }^{97}$ In this $18^{\text {th }}$ century world where war and commerce were bound together, not only did 'the merchant become the sovereign', as one contemporary observed, ${ }^{68}$ but also the sovereign needed in part to become the merchant.

As far as the East India Company were concerned the effect of this was, if not quite to reaffirm the legal result of EIC $v$. Sandys, then at least to provide the conditions in which the Company could continue to operate as though the claims upheld in that case were true. The Company was perfectly positioned to operate within this new era of statecraft through commercial competition. ${ }^{69}$ It cemented a position at the very heart of the metropolitan world of high finance because of the 'demands imposed upon the British state by recurrent warfare with other European powers. ${ }^{7} 70$ There were both financial and strategic elements to the Company's relationship with the state. As one of the great money engines of state, the Company provided a nodal point connecting the City of London, the state, and the empire in a network of relationships based on mutual indebtedness. ${ }^{71}$ But the Company's own activities reveal that the $18^{\text {th }}$ century overlap of commerce and war was far more than a metaphor. On its own initiative, it waged a series of wars across the Indian subcontinent. The ultimate success of these wars helped make India an important strategic interest and a theatre of operations in Britain's worldwide struggle against other European states, especially France. The Company had an army at its disposal that was far larger than many European states. These forces were deployed by the British state in a number of campaigns around the world. ${ }^{72}$

In India, the Company acted frequently as an independent entity, a fully functioning state that was sovereign and autonomous, for all practical and some symbolic purposes too. ${ }^{73}$ Edmund Burke, the Company's implacable enemy, jibed that the Company had turned into 'a state in the disguise of a merchant'. In an important recent study, Philip Stern takes Burke at his work, arguing that the term 'Company-State' best fits what really went on:

The Company did what early modern governments did: erect and administer law; collect taxes; provide protection; inflict punishment; perform stateliness; regulate economic, religious, and civic life; conduct diplomacy and wage war; make

${ }^{66}$ Istvan Holt, Jealousy of Trade: International Competition and the Nation-State in Historical Perspective (Cambridge, Mass.: Harvard University Press, 2005), 5-6.

${ }^{67}$ Holt, Jealousy of Trade, 13.

68 Ibid., 10.

${ }^{69}$ Adam Smith, An Inquiry into the Nature and Causes of the Wealth of Nations (1776) II.v.31: 'the great object of the political economy of every country is to increase the riches and power of that country.'

${ }^{70}$ Huw Bowen, The Business of Empire: The East India Company and Imperial Britain, 1756-1833 (Cambridge: Cambridge University Press, 2006), 30.

71 Bowen, Business of Empire, 30.

72 Ibid., 47.

${ }^{73}$ Dirks, Scandal of Empire, 169. 
claims to jurisdiction over land and sea; cultivate authority over and obedience from those people subject to its command. ${ }^{74}$

In no real sense was this sovereign-like activity directed or controlled by the metropolitan government. (Nor could it have been given that a late $18^{\text {th }}$ century exchange of despatches between Bombay and London took around 18 months.) Territorial expansion in India (by war and treaty) was not directed from Britain but resulted from the opportunism of Company's servants on the ground. ${ }^{75}$ (The Company Directors back in London were almost always far less belligerent and far more risk averse.) 'It was a classic case of what has been called "sub-imperialism", that is, of the dominance of local interests over metropolitan ones. ${ }^{76}$ There were, it is true, various parliamentary inquiries into the Company (and the 'Oriental excesses' of its trade and its rule). And these sometimes led to piecemeal attempts to imposed greater state control. ${ }^{77}$ But most politicians accepted the pragmatic argument that the Company offered the best way of securing profit and revenue from India. ${ }^{78}$ The pragmatic argument in some ways grew stronger as the Company became more powerful. 'By contemporary standards it was a gigantic organization. ${ }^{79}$ Such an important and visible part of Britain's strategic and economic powerbase, the Company could simply not be allowed to go to the wall. In our terms, the East India Company, whether 'sovereign' or not, was simply too big to fail.

\section{'COMPANY-STATE' OR 'ROgue STATE’?}

It is at this point that we return to the cases. The Company had become more deeply immersed in the problems of governing, as military and diplomatic successes from the 1760 s brought with them the new function as revenue collector (diwani). This, in turn, led the Company to undertake very substantial legal and administrative restructuring of the territories under its control. ${ }^{80}$ While the British government aimed to turn the Company into 'an administrative arm of the imperial state', ${ }^{81}$ there was a real sense in the metropolis that the Company was

${ }^{74}$ Philip J. Stern, The Company-State: Corporate Sovereignty and the Early Modern Foundations of the British Empire in India (Oxford and New York: Oxford University Press, 2011), 3-6. insert complete reference.

75 See, e.g., Supidta Sen, 'Liberal Economy and Illiberal Trade: The Political Economy of "Responsible Government" in Early British India' in Kathleen Wilson (ed.), A New Imperial History: Culture, Identity and Modernity in Britain and the Empire, 1660-1840 (Cambridge: Cambridge University Press, 2004).

76 Peter James Marshall, 'The British in Asia: Trade to Dominion, 1700-1765' in Marshall (ed.), The Oxford History of the British Empire, Vol. 1: The Eighteenth Century (Oxford: Oxford University Press, 1998), 499.

77 See especially the Regulating Act (1773) and the India Act (1784).

${ }^{78}$ Bowen, Business of Empire, 42.

${ }^{79}$ Marshall, 'The British in Asia', 488.

80 Sudpita Sen, Empire of Tree Trade: The East India Company and the Making of the Colonial Marketplace (Philadelphia: University of Pennsylvania Press, 1998).

81 Bowen, Business of Empire, 53. 
becoming a 'rogue state', 82 exercising sweeping powers under the banner of sovereign authority, beyond the control of the British state.

The case Nabob of the Carnatic (or Arcot) v East India Company (1791) turned on a number of treaties that the Company had concluded with the Nabob (or nawab) of the Carnatic, the ruler of an area of southern India over which the British had been competing with the French. By 1765, the Nawab had fallen under the Company's de facto control, which became de jure with his formal resignation of sovereignty in 1801.83 The case before the English courts sees the Nawab chafing against the realities of this creeping extension of imperial control. His lawyers claimed that the defendants had received more from the concession to collect revenue in the Carnatic than allowed under the treaties. Lawyers for the Company replied that both parties to the case, the Nawab and the Company, were 'sovereign independent powers' exercising the capacity of the prince to make peace or war with other princes. That power was outside the jurisdiction of the court, even if the prince had decided to delegate this power instead of exercising it himself. Seeking to exploit the confusion about the Company's status, the Nawab countered that the powers granted to the Company reflected its nature as 'a species of corporation created for the purposes of trade' and did not 'in any degree create them a sovereign, much less an independent state'. And even assuming that they had the power 'to rob any of the powers in India', that was no reason to prevent the court from forcing them to pay their debts. The court (eventually) held that while the Company could not claim the total exemption of a sovereign state from all jurisdiction, the fact that the source of their power ('participation in the prerogative') revealed a right to enter into federal treaties on behalf of Britain. The treaties on the basis of which the Nawab brought suit were 'engagements of a political nature and matters of State' that made the unamenable to the jurisdiction of the court.

Nabob of the Carnatic confirms that there was indeed a sovereign dimension to the East India Company's activities in India and that this dimension was as immune from the jurisdiction of ordinary law as any other sovereign act. ${ }^{84}$ This ruling was later confirmed in other cases. In Gibson v East India Company (1839), Tindal CJ said the Company possessed a twofold nature encompassing, first, the (private) power to carry on trade as merchants and, second, the (sovereign) power to acquire, retain and govern territory, to raise and maintain armed forces by sea and land, and to make peace or war.

Two final cases relate to the exercise of the Company's sovereign capacity. Elphinstone v. Bedreechund (1830) arose out of the declaration of martial law by the Company in the wake of the victory of British forces over the Peishwa. The

82 Nicholas B. Dirks, The Scandal of Empire: India and the Creation of Imperial Britain (Cambridge, Mass.: Harvard University Press, 2006), chapter 5.

83 About this interim period, Burke wrote: 'The Nabob, without military, without federal capacity, is extinguished as a potentate; but then he is carefully kept alive as an independent and sovereign power, for the purpose of rapine and extortion, - for the purpose of perpetuating the old intrigues, animosities, usuries, and corruptions.' (Quoted in Dirks, Scandal of Empire, 183-184.)

${ }^{84}$ Harrison Moore, Act of State, 105. 
former governor of a fortress in the region sought the return of property taken from him by British forces. He had been kept under house arrest some distance from where there was still actual fighting. Government lawyers argued that military necessity must provide the basic legal framework in this context. Any other approach, they said, 'would tend to unnerve the arms of the soldier, and to render quite fruitless the conquest he had obtained'. The position was simple. A conquering army commander has a choice: 'he may either deliver it up to the ravages of his soldiery, if he is cruelly disposed, or may place commissioners in it to preserve tranquillity, till final arrangements are made respecting it [...] but this does not deprive the commander of his power, or free the country from military government.' The court agreed. What took place was a hostile seizure made while war had not ceased and so could not be adjudicated on by any court. There is an interesting footnote to the case. The judge later advised the plaintiff to petition the King in Council. The same judge sitting on that (political) body advised the king on the basis of evidence presented before court that the treasure seized should in fact be returned to the plaintiff. It may be, then, that Bedreechund got his property back. But if he did so it was out of royal grace and not through legal right.

Secretary of State in Council of India v Kamachee Boye Sababa (1859) also involved a seizure of property. The British, by now entrenched practically everywhere in the subcontinent, assumed control of the Raj of Tanjore when the Rajah died without an obvious heir. A series of treaties concluded between the East India Company and successive Rajahs had already given the British very substantial powers but no de jure sovereign rights over the territory. Nonetheless, on the Rajah's death, the Company simply declared that the Raj had lapsed to the British government and seized the late Rajah's property. In court, the Rajah's widow claimed that some of that property was the personal property of the Rajah as opposed to public property belonging to the Raj. The government argued that the taking of the property was an act of State, and so no court had jurisdiction to entertain the question. At first instance, the court accepted that the Company must be 'considered to have become the Sovereign power throughout the kingdom of Tanjore from the death of Rajah Sevajee' despite the lack of public pronouncement or legal title. But this gave them no right to the personal property of the late Raj, which ought to be returned to his widow. That decision was overturned on appeal. Lord Kingsdown held that: (i) if the court cannot inquire into the an act because it is an act of state, it cannot inquire into any part of that act; (ii) the government in this case intended to seize all property, whether public or private; (iii) it intended to act according to its own notions of what is just and reasonable, not those of the court; and (iv) it was perfectly fine for the government to act through a delegate, in this case the East India Company. 


\section{CONCLUSIONS TO THE SECTION}

One simple point can be made about the cases we have looked at involving the East India Company. It was perfectly possible to delegate sovereign capacity not just to state officials other than the sovereign but also to servants of a private company operating for profit. That is what the judges in Sandys case sketched in outline, while thinking they were upholding the power of the king. That outline was filled in by the court in Nabob of the Carnatic when it decided that the Company could not be bound to the obligations of treaties it had signed with native princes. And that position was underscored in a series of decisions that followed, including those in Elphinstone and Kamachee Boye Sahaba concerning acts that look quite a lot like theft by the Company of native property.

A more involved point relates to the type of 'law' that is evidenced in these decisions. It is common law, but not as we know it. The world imagined in these cases is a long way from that articulated by the state theory of Hobbes or Locke or at least their internal, civic dimensions. It is the world of force and the pact. Wotan steps out of Valhalla and becomes the Wanderer. Not that it is an entirely lawless world. Treaties can be made, which take legal form. And martial law provides at least the rudiments of legal order. Principles - derived from the law of nations, or natural law, or Roman Law - float around the margins, particularly when European state collides with European state. But this law, at least in its operation, is paper thin. It provides almost no break on superior force or on the manipulation of legal forms in self-interested ways.

\section{WHICH REASON?}

The French historian Michelet once suggested that France was a person, Germany a people, and England an empire. He may well have been on to something, judging from the reason-of-state cases we examined in the previous section. The courts consistently accepted that the 'reason' of reason of state need not be that of the sovereign, whether in the personal sense as per Locke's prerogative, or in the formal or institutional sense as per Hobbes. In deciding that a private corporation, operating for its own profit and granted vast discretionary authority from the public authority, was entitled to exercise broad sovereign powers in respect of at least some of its activities, the courts articulated principles to reflect the pragmatic reality of a commercial empire.

But what reason is meant when such reason-of-state arguments are pressed? It cannot be reason in its substantive sense - the reason that inhered to legality in the Aristotelian model. Nor can it be (in any straightforward sense) the formal institutional reason of modern state theory. Nor can it be an appeal to popular reason of the type realized in the later republican state theory of Rousseau ('general will') or the earlier watered-down version propounded by Locke ('right of 
rebellion'). Reason of state worked in the cases we examined as an exclusionary force. It operated to steer the court away from precisely the concerns of reason in any of these legal forms, either into an entirely different domain or at least to transpose them into a different legal register. In Sandys, for instance, the move was away from the common law (property rights) and into the realm of the law of nations and religious law (prerogative). In Nabob of the Carnatic, the move was towards the law applicable to the pact-based world of princes. The claim is not (quite) that we are bound by no law, but that 'we are under another Law', over which you (the court) have little or no authority.

What law might that be? Under what reason is it constituted? It is rarely in the interest of those claiming reason of state to spell out the contours of that law with any real precision. But what seems to be claimed is something like the mirrorimage of Sir Edward Coke's defence of common law as 'artificial reason' - that is, a type of learning only acquirable through experience and training, and thus immune from interference from those without such experience. Indeed, Botero in his The Reason of State [1589] makes something like this point when he remarks that a ruler's actions 'cannot be considered in the light of ordinary reason'. ${ }^{85}$ Reason of state is the reason of rulers or their agents - acting outside at least the normal structures of the state and possibly also outside their sovereign capacity. The justifications that we associate with reason-of-state claims - the argument from necessity, the argument from secrecy, salus populi, and so on - are ancillary and contextual.

Underpinning this approach is the conviction that something beyond the artificial framework of ordinary laws is required in order for the state to thrive, something more by way of an 'active' intelligence. This was the sentiment expressed in Luther v. Borden - without it, 'Government would be a mere parade'. 86 A much earlier attempt to navigate between a state (rigidly) governed through law and the need for active intelligence is to be found in Plato's The Laws. In that late work, Plato goes into some considerable detail in specifying the institutional framework for his 'second-best' state. By far the most intriguing aspect of his design is a body he calls the 'nocturnal council' (nukterinos sullogos). ${ }^{87}$ So called because it meets before dawn in order to prepare proceedings for the day to come, this last body is composed of the ten most senior nomophulakes or 'guardians of the law'.88 The Laws is brief in its account of the nocturnal council and its tasks -

85 Quoted in Quentin Skinner, The Foundations of Modern Political Thought, Vol. 1: The Renaissance (Cambridge: Cambridge University Press, 1978), 249.

8648 US 1 (1849)

${ }^{87}$ In the original text, the nocturnal council is explicitly mentioned only twice. Its name does not carry a formal connotation in the Greek. 'The very name of the body', V. Bradley Lewis argues, 'suggests and informal body unlike the usual political institutions of the city. A more accurate, albeit homely, English translation would render nukterinos sullogos as something like 'nightly conference' or 'nightly meeting'. (V. Bradley Lewis, 'The Nocturnal Council and Platonic Political Philosophy' (1998) 19 History of Political Thought $1,15$.

${ }^{88}$ Laws 951e. 
perhaps this is deliberate. Plato does say, however, that its discussion must centre on the city, the problems of legislation, and anything pertinent learned from other cities. Members 'must be particularly concerned with those studies which promise, if pursued, to further their researches' by throwing light on otherwise obscure legislative problems. ${ }^{89}$

The nocturnal council has few formal powers. And yet the Athenian Stranger (Plato's protagonist here) refers to it as the 'anchor' of the whole city, a 'safeguard of the laws' which 'would keep safe everything we wanted it to'. ${ }^{90}$ It seems likely that Plato envisaged that the council might exercise an informal steering and educative role on the other officers of state and, through them, the people. Its influence is to be found 'in the interstices and looser joints of the legal structure, not contradicting but supplementing the rule of law'. ${ }^{91}$ This indirect but pervasive influence stems partly from the council's composition - the men who sit on it hold many of the city's most senior officials. It also arises from the nature of the council's task. Plato sees that the state he describes requires at least some of its officials exercise the philosophical and juristic intelligence needed to preserve, expound and apply the principles on which the laws are based..$^{92}$ The nocturnal council provides the central forum for just this process of reflection. As such, it makes possible just the kind of injection of philosophy into a system of rule that Plato consistently advocated. ${ }^{3}$ The body, Plato says, is to constitute the Intelligence, or Nous, of the state'; 94 and it exists to make the life of the city subject to the intellect.

The specifics of Plato's institution are, of course, alien to us, as are some of the specifics of the role that it was meant to play. But might it not be the case that Plato has mapped out the basic structure of reason of state - operating in semisecrecy; sovereign (in a very soft sense); offering guiding intelligence; based in reason allied to experience; a soft law body that is also guardian of the laws?

\footnotetext{
${ }^{89}$ Laws 951e-952a.

${ }^{90}$ Laws 960d \& 961c.

91 Glenn R. Morrow, 'The Demiurge in Politics: The Timaeus and the Laws' (1953) 27 Proceedings and Addresses of the American Philosophical Association 5, 19.

92 Morrow, Plato's Cretan City (Princeton University Press, 1993), 23.

${ }^{93}$ For instance, Plato argues in his Seventh Epistle that the only solution to the problem of civil strife (stasis) is the injection of philosophy into the regime.

${ }^{94}$ Morrow 'The Demiurge in Politics', 17.
} 